Article

\title{
Course Analysis of Library and Information Science in Korea
}

\author{
Yelim Mo, Euntaek Seon, Goun Park and Haklae Kim *
}

The Department of Library and Information Science, Chung-Ang University, 84 Heukseok-ro, Heukseok-dong, Dongjak-gu, Seoul 06974, Korea; ye3031@gmail.com (Y.M.); sun1192612@gmail.com (E.S.); goun17@naver.com (G.P.)

* Correspondence: haklaekim@cau.ac.kr

Received: 23 October 2019; Accepted: 25 December 2019; Published: 27 December 2019

\begin{abstract}
Curriculums play a key role in implementing the educational goals and directions of a university. Universities regularly update their curriculums to actively respond to internal and external environmental changes. Korean universities face challenges, including a steady decline in enrollment and demand-oriented convergence education. Because of the nature of convergence science, library and information science should respond more actively to new challenges. This study analyzes the current status of library and information science courses according to subjects and universities. Data was collected from the websites of each university, and various methods such as text analysis, frequency analysis, and network analysis were applied to investigate current status of LIS in Korea.
\end{abstract}

Keywords: library and information sciences; course; curriculum; data analysis

\section{Introduction}

Library and information science (LIS) is the study of the theory and practice of processing, retrieving, collecting, distributing, using, manipulating, and accumulating information resources through a link with information technology (IT) [1]. In general, LIS consists of library science, which is the starting point of the study; bibliography, which focuses on the analysis and interpretation of books; records management, which focuses on the management and preservation of records; information science, which focuses on information access and processing; and knowledge organization, which is about document indexing and classification performed in libraries. Thus, LIS is an interdisciplinary field of study [2,3] dedicated to the logical and scientific identification of facts and phenomena associated with literature and the pursuit of social applicability $[4,5]$.

Korean universities are under great pressure from environmental changes [6]. First, the continuous decline in the number of students admitted to college is perceived as an intrinsic crisis that threatens the survival of universities. Second, interdisciplinary education is emerging as a core goal of colleges and universities. For this reason, universities face new challenges in the form of restructuring colleges and reforming academic curricula. The convergent nature of LIS has both positive and negative effects on university change. In particular, LIS would be sensitive to changes in IT. Recent trends represented by artificial intelligence, data science, and big data are affecting various academic fields beyond computer science. Informatics-related courses in LIS should be reorganized to accommodate demand-driven changes. Since these changes are ongoing, various attempts have been made to develop a variety of discussions and alternatives. Research is being conducted on the LIS curriculum. Noh [7] proposed a standard model for the curriculum content of major subjects in LIS, while Lee [8] researched ways to improve the LIS curriculum. However, there has been no relevant research since 2014. On the other hand, Sungkyunkwan University, Yonsei University, and Kyungpook National University are 
participating in i-School [9], and they operate specific programs that combine existing courses with information technologies. Kangnam University has established a department of industrial data science to integrate its LIS and data science courses (Major in Data Science).

The department's curriculum is the key to implementing educational goals and directions. Individual departments constantly update their curriculum to respond to changes in their environment. Therefore, courses included in the curriculum can reveal the academic identity of the department. This study investigates characteristics of curricula in the area of LIS in Korea and discusses whether they reflect the recent technology trend centered on information science. We collected curriculum information from websites published by LIS departments, classified subjects based on the academic research field, and analyzed the characteristics of subjects by universities. This paper is organized as follows: Section 2 examines previous studies on the academic scope and curriculum of LIS. Section 3 describes the data collection and methods. Section 4 describes our findings from the data analysis. Section 5 discusses the characteristics of LIS courses in Korea and some limitations of this research. Then, Section 6 concludes.

\section{Related Work}

A number of studies have been conducted to analyze the courses of LIS [10-13], and directions of library studies in accordance with the development of IT [14-16]. Wyman and Imamverdiyev analyzed similarities and differences in the LIS program from 1997 to 2017 [17]. Numerous similarities in changes were observed in LIS education, such as the changes in the curricula. It is significant for LIS programs across the globe to realize that their changes in curricula and programs are similar to other LIS programs. Siddiqui and Walia examined the status of LIS postgraduate courses in India and the UK [18].

Some research has presented the impacts of information technologies in the area of the library and library science [14]. IT has tremendously influenced and changed library and information services in libraries and information agencies [19]. The education of LIS professionals is also strongly impacted by IT because of the current need for changed competencies of professional librarians and information scientists and the consequent changes in educational pedagogies and instructional techniques $[16,19]$. Informatics, for example, develops in relation to theories and applications of computer science including information retrieval, information systems, and databases. Joseph and Aneesh suggested that LIS education must be changed to be more IT-oriented, practical, and technical, which can help the students in developing their skills for better community service [20]. Yi and Turner analyzed the curricula of school librarianship courses in the USA and concluded that the changing technological landscape requires educational programs to change existing curricula to meet new educational and professional demands [21].

In Korea, LIS was formerly called library studies; however, since 1990 it has been developing into a convergent study in accordance with the changes in the paradigm of IT [6]. In 1985, Chonnam National University established a department dedicated to LIS for the first time in Korea. However, the curriculum varies based on the academic vision of each university, and the academic fields covered are different [22-24]. There is an ongoing need to improve the educational programs of library and information sciences. In recent years, discussions have been made in earnest to establish a new identity for library and informatics in conjunction with the restructuring of universities and to cope with new changes [6]. In addition, it is time to discuss how to respond to trends that can converge in LIS, such as data science and big data. However, previous studies tend to investigate the subjects based on the traditional framework of LIS, which lacks an interlinking with new academic topics [24].

\section{Data Collection and Methods}

This study collects subject information established in the departments of library and information science and analyses the current status according to subjects and universities. Data was collected from the websites of each university, and frequency analysis and network analysis were applied [25]. 
There are 408 universities in Korea, and 32 of them have a department of LIS. We collected curriculum information from websites provided by 34 universities from July to August in 2019, and extracted the details of 1123 courses. Note that two additional universities are included in the datasets: Daegu Catholic University has a department of library science, and it was included in the data because the difference only pertains to the department name. Korea Nazarene University has a department of braille LIS, and it was included in the data, apart from those areas related to braille. Data collection was based on information published on the websites of individual departments. The analytical data was refined based on the following rules:

- If the Korean name of a subject is different from the English name, the subject name in English is used (Example: Management of School Libraries $\rightarrow$ School Library Management).

- If the Korean name of a subject is different but the English name is the same, the English name is used (Example: Database Theory, Introduction to Databases, Understanding Databases $\rightarrow$ Introduction to Database).

- If the name of a course is combined with a number, it is defined as a name without numbers (Example: Major Reading 1, Major Reading $2 \rightarrow$ Major Reading).

The average number of subjects per school is 33.1. Keimyung University offers the highest number of courses (52 courses), whereas Duksung Women's University offers the lowest number of courses (23 courses). The four braille-related courses at Korea Nazarene University were excluded. The collected datasets are publicly available (https:/ / github.com/haklaekim/lis).

Course classification follows the academic research field classification (https://github.com/ haklaekim/lis/blob/master/research-classification.csv) defined by the Korea Research Foundation (https://www.nrf.re.kr/index). This classification system is used for the efficient promotion and management of academic research support projects in Korea. LIS is divided into 13 categories: Archival Studies/Conservation, Digital Libraries, General Library and Information Science, Information Organization, Information Resources/Media, Information Retrieval, Information Services, Information Technology, Informetrics, Korean Bibliography, Library/Information Center Management, and LIS Education. Note that there are some subjects that are difficult to align in the academic research field classification, depending on the characteristics of the department. The "Others" category is added as a new category to categorize these cases.

\section{Results}

\subsection{Current Status of Courses}

Table 1 presents the course status by category and by division of the academic research classification. A division is a subcategory of the major categories and varies depending on the category. For example, the General Library and Information Science (LIS) category includes the following subcategories: Information/Library Policy, Comparative Literature Informatics, and Library History, whereas Information Services does not have any divisions.

The top five categories (i.e., Library/Information Center Management (183), Information Organization (182), Information Technology (131), General LIS (128), and Information Resources/Media (103)) comprise $64.8 \%$ of the total. Library/Information Center Management includes comprehensive subjects on library management, including library resources, service, systems, and policies. Information Organization has subtopics such as knowledge organization and classification, indexing, and metadata. Information Technology, ranked in the top three, deals with topics related to information systems. General LIS and Information Resources/Media comprise of topics on library policy and history and the theories and practices of various information resources. Note that information science, which combines relevant subjects such as Information Technology (131), Information Resources/Media (103), Information Retrieval (83), Information Services (78), and Informetrics (11), occupies $29 \%$ (323 courses). It can be interpreted that information science can be seen 
to be important to LIS overall. On the other hand, some categories have relatively low frequencies. For example, Archival Studies/Conservation has approximately $4.6 \%$ of subjects. Similarly, there are 39 courses in the Bibliography category and 25 courses in Digital Library. Some courses are difficult to classify into categories in the academic research field classification. Many courses on topics such as practice and exercise, publication, special lectures (job, career, and seminar), and employment are included in "Others".

Table 1. Frequency of courses, based on the academic research classification.

\begin{tabular}{|c|c|c|c|}
\hline Categories & $\begin{array}{l}\text { Total Number of } \\
\text { Courses (Percentage) }\end{array}$ & Divisions & $\begin{array}{l}\text { The Number } \\
\text { of Courses }\end{array}$ \\
\hline $\begin{array}{l}\text { Library/Information } \\
\text { Center Management }\end{array}$ & $183(16.3 \%)$ & $\begin{array}{l}\text { Library/Information } \\
\text { Management }\end{array}$ & 183 \\
\hline Information Organization & $182(16.2 \%)$ & $\begin{array}{l}\text { Information Organization } \\
\text { Classification } \\
\text { Cataloging/Metadata } \\
\text { Indexing and Abstracting } \\
\text { Terminology/Thesaurus }\end{array}$ & $\begin{array}{l}73 \\
74 \\
22 \\
10 \\
2\end{array}$ \\
\hline Information Technology & $131(11.7 \%)$ & Information Technology & 131 \\
\hline General Library \& Information Science & $128(11.4 \%)$ & $\begin{array}{l}\text { Library and Information Science } \\
\text { Information/Library Policy } \\
\text { Library History }\end{array}$ & $\begin{array}{l}86 \\
19 \\
23\end{array}$ \\
\hline Information Resources/Media & $103(9.2 \%)$ & Information Resources/Media & 103 \\
\hline Others & $96(8.5 \%)$ & $\begin{array}{l}\text { Others } \\
\text { Publication } \\
\text { Career/Seminar }\end{array}$ & $\begin{array}{l}54 \\
13 \\
29 \\
\end{array}$ \\
\hline Information Retrieval & $83(7.4 \%)$ & $\begin{array}{l}\text { Information Retrieval } \\
\text { Automatic Indexing/Summary } \\
\text { Automatic Classification/Clustering } \\
\text { Retrieval Models and Techniques } \\
\text { Database }\end{array}$ & $\begin{array}{l}44 \\
0 \\
4 \\
2 \\
33\end{array}$ \\
\hline Information Services & $78(6.9 \%)$ & Information Services & 78 \\
\hline $\begin{array}{l}\text { Archival Studies/Conservation } \\
\text { Korean Bibliography }\end{array}$ & $\begin{array}{l}52(4.6 \%) \\
39(3.5 \%)\end{array}$ & $\begin{array}{l}\text { Archival Studies/Conservation } \\
\text { Korean Bibliography }\end{array}$ & $\begin{array}{l}52 \\
39\end{array}$ \\
\hline Digital Libraries & $25(2.2 \%)$ & Digital Libraries & 25 \\
\hline LIS Education & $13(1.2 \%)$ & LIS Education & 13 \\
\hline Informetrics & $11(1.0 \%)$ & Informetrics & 11 \\
\hline Total & $1124(100 \%)$ & Total & 1124 \\
\hline
\end{tabular}

There is a wide range of courses on the theory and concept of LIS. Table 2 summarizes individual courses based on the categories, with their occurrences. There are many course names that are the same as the category names and are relatively frequent. Each university has their own courses with unique names, whereas course names differ slightly among different universities. For example, some keywords such as "Introduction", "Understanding", "Interpretation", and "Theory", are often used in course names. These would be similar or the same subjects. However, we could not conclude this fact because there is a limitation in that the actual content of each course is not analyzed. The Information Retrieval category has various courses, including automatic indexing/summaries, automatic classification/clustering, retrieval models/techniques, and databases. It is worth noting that "Information Retrieval" as a course name exists in 29 universities. Digital Library and Information Education did not have many courses, and there were no courses related to comparative bibliographic information science. 
Table 2. Top five established courses, by categories, with their frequencies.

\begin{tabular}{|c|c|c|c|}
\hline Categories & $\begin{array}{l}\text { Total Number } \\
\text { of Courses }\end{array}$ & Top 5 Courses & Courses (Frequency) \\
\hline $\begin{array}{l}\text { Library/Information } \\
\text { Centre Management }\end{array}$ & 183 & $56(30.6 \%)$ & $\begin{array}{l}\text { Reading Guidance (21), Public Library Management (15), Library Management (8), School Library } \\
\text { Management (7), Reading Education (5) }\end{array}$ \\
\hline $\begin{array}{l}\text { Information } \\
\text { Organization }\end{array}$ & 182 & $46(25.2 \%)$ & $\begin{array}{l}\text { Collection Management (12), Metadata (11), Library Classification (8), Collection Development (8) } \\
\text { Material Organization Practice (7) }\end{array}$ \\
\hline $\begin{array}{l}\text { Information } \\
\text { Technology }\end{array}$ & 131 & $23(17.5 \%)$ & $\begin{array}{l}\text { Information Systems (6), Information Literacy (6), Introduction to Information Technology (4) } \\
\text { Information Networks (4), User Interfaces (3) }\end{array}$ \\
\hline General LIS & 128 & $68(53.1 \%)$ & $\begin{array}{l}\text { Introduction to Library and Information Science (29), Introduction to Information Science (15), History } \\
\text { of Information and Culture (9), History of Libraries (8), Research Methods for Library and Information } \\
\text { Science (7) }\end{array}$ \\
\hline $\begin{array}{l}\text { Information } \\
\text { Resources/Media }\end{array}$ & 103 & $33(32.0 \%)$ & $\begin{array}{l}\text { Children and Youth Materials (10), Information Media (9), Information Resources by Subject Specialties } \\
\text { (7), Science and Technology Information (4), Reference Information Resources (3) }\end{array}$ \\
\hline Others & 96 & $26(27.0 \%)$ & $\begin{array}{l}\text { Library Practice (6), Seminar in Library and Information Science (6), Library Field Workshop (5), Field } \\
\text { Studies in Information Organization (5), Electronic Publishing (4) }\end{array}$ \\
\hline Information Retrieval & 83 & $43(51.8 \%)$ & $\begin{array}{l}\text { Information Retrieval (29), Databases (4), Database Systems (4), Online Information Retrieval (3) } \\
\text { Introduction to Web Databases (3) }\end{array}$ \\
\hline Information Services & 78 & $40(51.2 \%)$ & Information Services (29), Information User Studies (8), Information Distribution (3) \\
\hline $\begin{array}{l}\text { Archival } \\
\text { Studies/Conservation }\end{array}$ & 52 & $30(57.6 \%)$ & $\begin{array}{l}\text { Introduction to Records Management (20), Records and Information Management (3), Information } \\
\text { Data Conservation (3), Management of Classical Materials (2), Record Management Systems (2) }\end{array}$ \\
\hline Korean Bibliography & 39 & $25(64.1 \%)$ & $\begin{array}{l}\text { Introduction to Bibliography (17), LIS Chinese Classics Translation (2), Introduction to Chinese } \\
\text { Characters (2), Classical Book Translation (2), Korean Bibliography (2) }\end{array}$ \\
\hline Digital Libraries & 25 & $23(92.0 \%)$ & $\begin{array}{l}\text { Digital Library (18), Building Digital Libraries (2), Digital Contents (1), Digital Library Systems (1) } \\
\text { Understanding Digital Libraries and IT (Capstone Design) (1) }\end{array}$ \\
\hline LIS Education & 13 & $9(69.2 \%)$ & $\begin{array}{l}\text { Information Literacy Instruction (5), Policies and Education of Information Professionals (1), Library } \\
\text { Instruction (1), User Instruction in Library (1), Information Use Education (1) }\end{array}$ \\
\hline Informetrics & 11 & $6(54.5 \%)$ & $\begin{array}{l}\text { Knowledge Structure (2), Basic Statistics in Library and Information Science (1), Data Metrics } \\
\text { and Analysis (1), Statistical Methodology in Library and Information Science (1), Numeric Data } \\
\text { Processing (1) }\end{array}$ \\
\hline Total & 1124 & 428 & - \\
\hline
\end{tabular}


To investigate associations between universities and courses, a chi-square analysis is performed. However, the given dataset does not met the conditions for this test. More than $70 \%$ of cells have an expected value less than 5 . In this case, an alternative approach with $2 \times 2$ contingency tables can be used (i.e., Fisher's exact test). For this test, we selected three universities that participate in i-School, and their courses. In particular, courses are divided into two categories: Informatics (e.g., information retrieval and information technology) and Non-Informatics. Kyungpook, Sungkyunkwan, and Yonsei have 23, 23, and 22 non-informatics courses and 11, 17, and 16 informatics courses, respectively. Let $X$ be a university, and let $Y$ be two categories (i.e., Non-Informatics and Informatics) appearing in the selected universities. Then the relevant matrix can be represented as shown in Table 3 .

Table 3. The result of Fisher's exact test using universities and courses.

\begin{tabular}{ccccc}
\hline & Kyungpook & Sungkyunkwan & Yonsei & Total \\
\hline Non-Informatics & 23 & 23 & 22 & $R_{1}=68$ \\
Informatics & 11 & 17 & 16 & $R_{2}=44$ \\
Total & $C_{1}=34$ & $C_{2}=40$ & $C_{3}=38$ & $N=112$ \\
\hline
\end{tabular}

The $p$-value $=0.6595$, which is larger than 0.05 and is not significant. In this case, there is no statistically significant association between two categories. Therefore, we analyzed the current status of individual categories based on their occurrences and then introduced relationships between individual courses by using network analysis.

\subsection{Characteristics of Schools}

Library/Information Center Management is the highest category, with more than one course offered at every school. As shown in Figure 1, Korea Nazarene University has $36.4 \%$ of subjects in this category. Daegu University and Keimyung University also show a high percentage of subjects in this category. Given that the others in the top five universities are between $20 \%$ and $30 \%$, the educational goals of Korea Nazarene University seem to be clearly reflected. Information Organization has the highest percentage at Jungbu University (25.9\%), Silla University 25\%), Gwangju University (24.1\%), Cheongju University (23.1\%), and Chung-Ang University (21.6\%) (see Figure 2). The curriculum of Jungbu University provides a relatively large number of subjects related to information organization. It is noteworthy that Gwangju University offers more than five courses related to classification in the field of information organization.

As shown in Figure 3, IT has the most subjects at Yonsei University $(28.9 \%)$ and Sungkyunkwan University (27.5\%). Yonsei University has courses in data processing and analysis such as information system analysis, database systems, and introduction to text processing. Sungkyunkwan University has courses such as information analysis, data analysis, and databases. In particular, they operate data science as a separate major, which is focused on data analysis. Jeonju University specializes in the subject of linked data.This field includes courses on LOD (linked open data) information services, information sharing and LOD, LOD implementation practice, information sharing and XML link semantic web technologies, and open data in the bibliographic information domain. Kyungpook National University's Information Retrieval (17.6\%), Busan National University's Information Resources/Media (20\%), and Ewha Women's University's Archival Studies/Conservation (16.7\%) are not included in the top rankings, but these subjects have the highest percentage of courses at the aforenamed universities.

Chung-Ang University has newly established courses for data-intensive analysis such as data science and data visualization. The involvement of the department of LIS in i-School is a new trend that reflects the importance of informatics. Five universities have joined i-School in Korea, of which four are departments of LIS. The percentage of informatics subjects $(22.3 \%)$ in universities enrolled in i-School is more than twice as high $(10.5 \%)$ as in universities that are not enrolled. These results can be interpreted as the universities actively responding to new IT fields while maintaining the theoretical 
framework of LIS. In particular, based on the interdisciplinary characteristics of the schools that have joined i-School, they are trying to expand their academics and academic departments and respond to changes in the times.

There is also one example of establishing a specialized curriculum in conjunction with key areas of LIS. Sangmyung University offers medical-related subjects such as medical terminology and MeSH, and health information centers. On the other hand, there are few schools that offer Bibliography, Digital Library, Informetrics, or Information Education courses. In particular, Information Education does not have any courses in 23 universities. Informatics is only available at eight universities. Bibliography has traditionally been in the mainstream of scholarship, but the number of schools at which it is offered is decreasing. Currently, nine universities, $26 \%$ of the total, do not offer courses in bibliography. Figure 4 visualises course proportions based on academic classifications at universities.

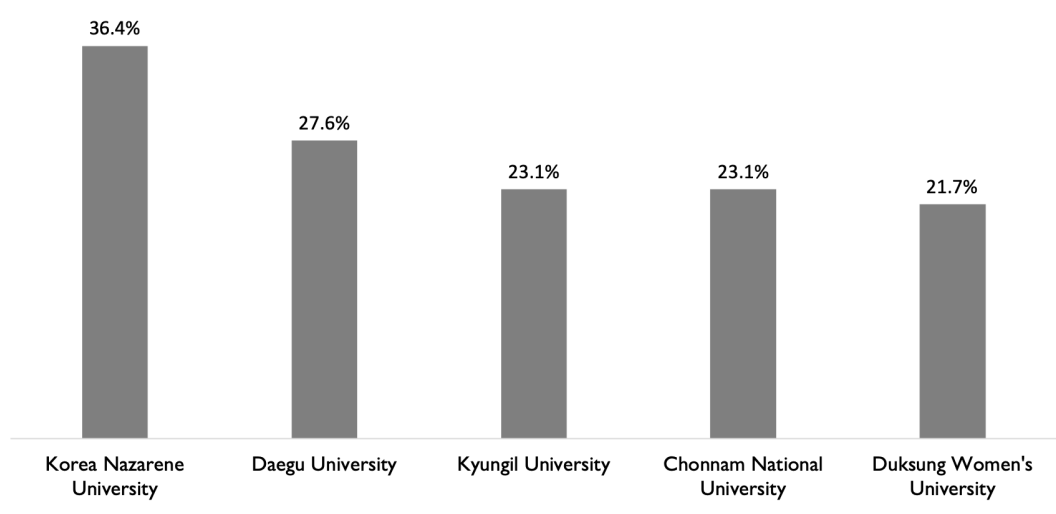

Figure 1. Top 5 universities with high frequencies of library/information center management-related courses.

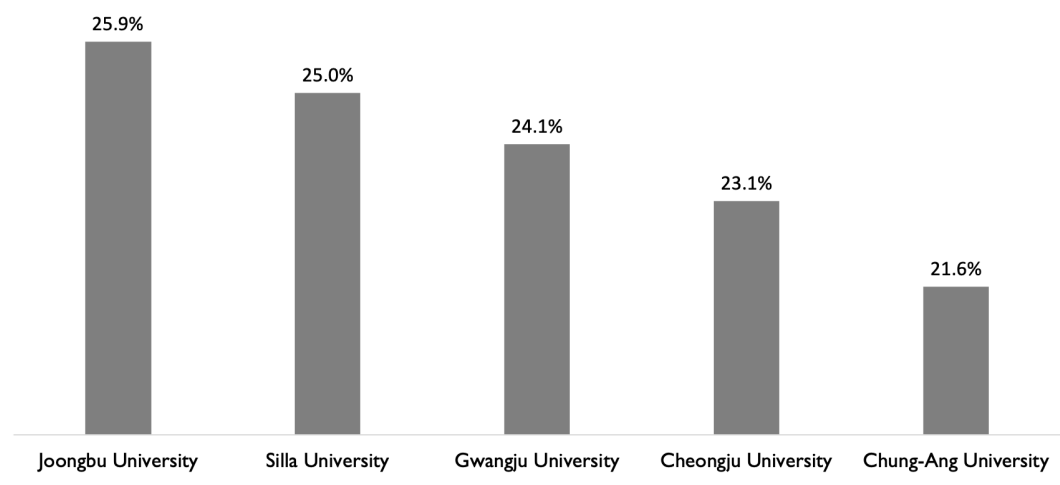

Figure 2. Top 5 universities with high frequencies of information-organization-related courses.

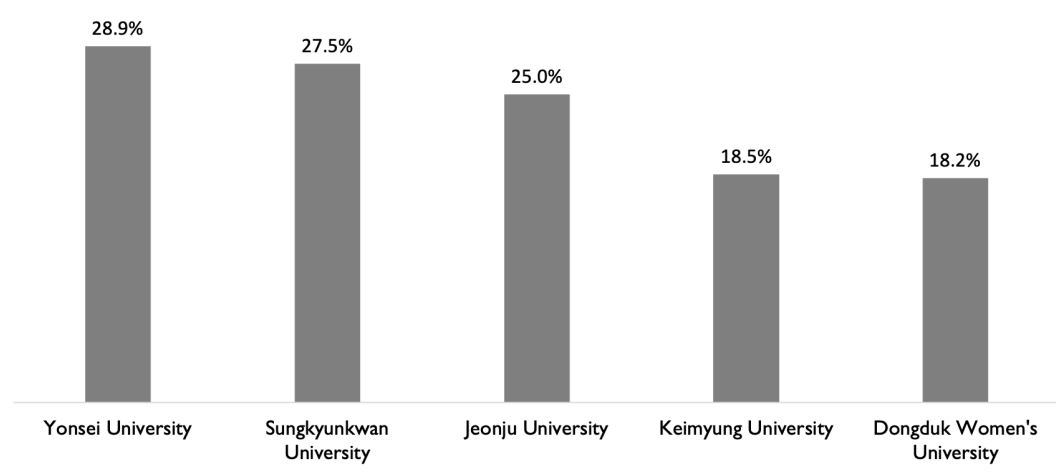

Figure 3. Top 5 universities with high frequencies of information-technology-related courses. 
Library / Information Center Management Organization of Information Information Technology L Library and Information Science in general Information Resources / Media

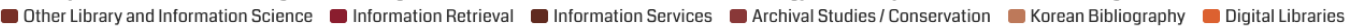

- LIS Education Informetrics

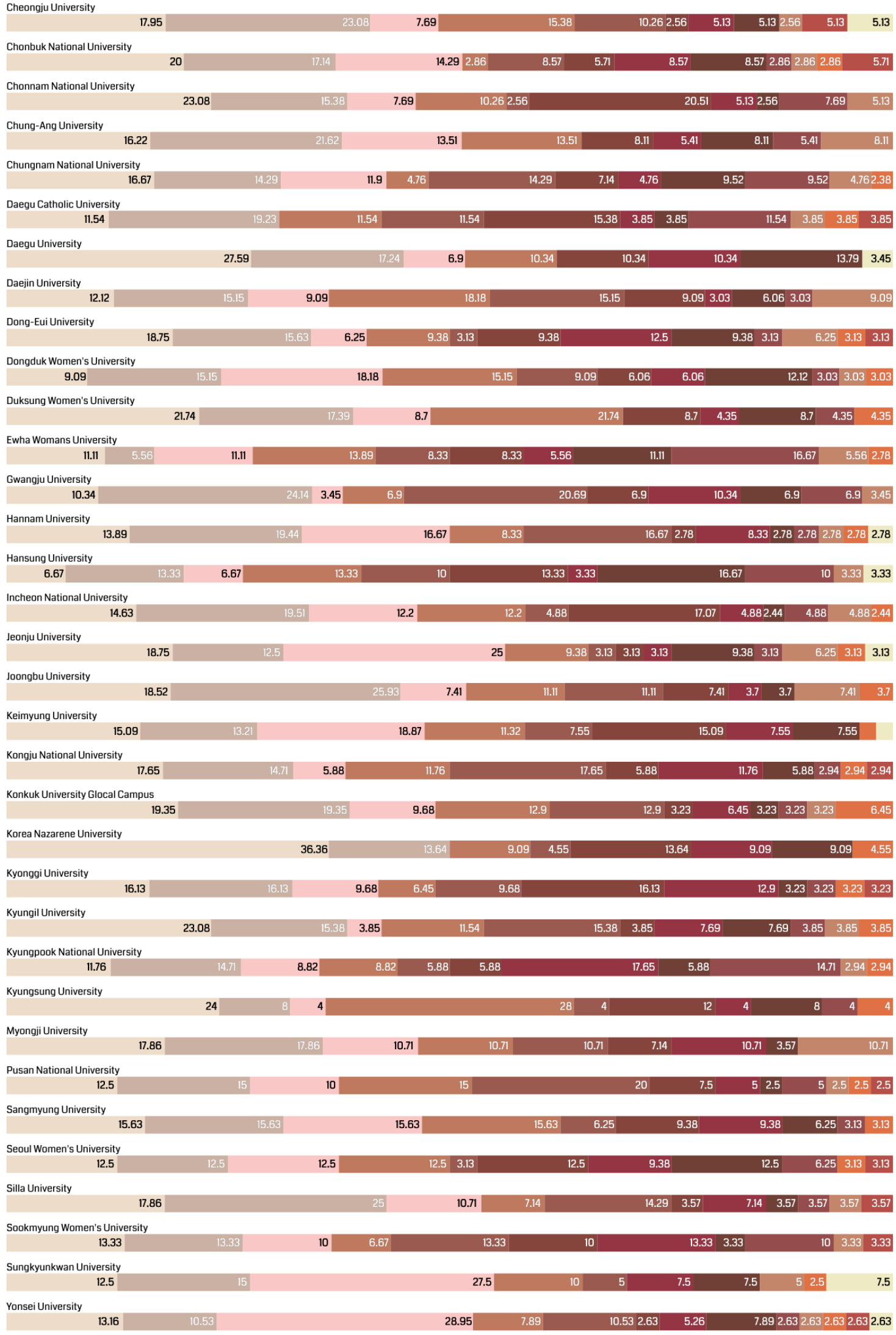

Figure 4. The percentage of courses based on the academic classification at universities. 


\subsection{Network Analysis}

The network of universities and courses contained a total of 800 nodes and 1176 edges. The average degree of links, i.e., the average connection between nodes, was 1.551. The maximum network diameter representing the distance between nodes in the network was six. In other words, the connection between each node is made within six steps. The average path length and density of the network were 3.814 and 0.004 , respectively. In summary, the curriculum network was characterized by low cohesion and relatively high connection distances. This result can be interpreted as the reason that there are a lot of similar nodes because the names of the courses are not uniform, and that the courses designed by individual schools have low commonality. Looking at the main results of the network analysis, it can be said that the subjects in Table 4 have a significant meaning in terms of connectivity and centrality. Information Retrieval, Introduction to LIS, Reading Guidance Practice, and Information Services have high betweenness and closeness centrality. The higher the closeness centrality, the shorter the path distance between the node and other nodes. For example, Information Retrieval, which has high values of betweenness centrality, may be frequently opened along with other subjects. The high value that this centrality refers to plays an important role in the connection between pairs or groups of specific nodes in the network. Subjects in the top 20 are considered to be influential nodes in the network. Lastly, harmonic closeness centrality is a value that considers the distance between nodes in the network to be disconnected in the calculation of adjacent centrality; it also considers the influence of nodes that do not interact with each other in the network.

Table 4. Betweenness centrality and closeness centrality of the top 20 courses according to a network analysis

\begin{tabular}{cccccc}
\hline Rank & Course Name & Degree & $\begin{array}{c}\text { Closeness } \\
\text { Centrality }\end{array}$ & $\begin{array}{c}\text { Harmonic } \\
\text { Closness Centrality }\end{array}$ & $\begin{array}{c}\text { Betweenness } \\
\text { Centrality }\end{array}$ \\
\hline 1 & Information Retrieval & 20 & 0.37627 & 0.42711 & 33034.15071 \\
2 & Introduction to LIS & 16 & 0.35845 & 0.40836 & 25499.20006 \\
3 & Reading Guidance Practice & 16 & 0.34868 & 0.39859 & 20066.38611 \\
4 & Information Services & 14 & 0.33274 & 0.38028 & 21789.78041 \\
5 & Korean Bibliography & 12 & 0.32832 & 0.37410 & 11829.18955 \\
6 & Library Information Center Management & 11 & 0.31764 & 0.36074 & 10367.49060 \\
7 & Digital Libraries & 11 & 0.30712 & 0.34726 & 8691.04966 \\
8 & Information and Reference Services & 11 & 0.31177 & 0.35332 & 8513.19923 \\
9 & Collection Management & 10 & 0.31255 & 0.35377 & 8950.96312 \\
10 & History of Libraries & 9 & 0.30636 & 0.34513 & 7978.06034 \\
11 & Information Media & 9 & 0.29633 & 0.33131 & 3533.69626 \\
12 & Metadata & 8 & 0.29919 & 0.33479 & 4932.32642 \\
13 & Information User Studies & 8 & 0.29992 & 0.33580 & 4828.55880 \\
14 & History of Information and Culture & 8 & 0.29375 & 0.32704 & 4500.78128 \\
15 & Library Management & 8 & 0.29609 & 0.33041 & 4211.89818 \\
16 & Reference Information Resources & 7 & 0.29213 & 0.32412 & 4796.42339 \\
17 & Knowledge Information Retrieval & 7 & 0.28894 & 0.31941 & 4148.14395 \\
18 & Records Management and Archives & 7 & 0.28894 & 0.31941 & 3974.70002 \\
19 & Collection Development & 7 & 0.29421 & 0.32716 & 3859.12906 \\
20 & Introduction to Information Science & 7 & 0.28782 & 0.31772 & 3611.87511 \\
\hline
\end{tabular}

\section{Discussion}

Curricula are very important in guiding the direction of education. LIS, which has an interdisciplinary nature, can expand theories and apply them practically through the connection of various disciplines. According to Borrego [26], who analyzed LIS education programs in 28 European countries, LIS education in undergraduate programs is made up of a combination of general culture with courses in technology, language, and practical education; postgraduate programs are not significantly different from undergraduate programs. Yi and Turner [21] analyzed the US curriculum, emphasizing the importance of skills and information literacy in LIS education, although the programs 
offered varied by school. In comparison, most Korean universities establish LIS as an independent major, with the difference of granting an undergraduate degree and librarian certification.

Informatics plays an important role in LIS. Information Technology and Information Retrieval comprise 214 of 1124 courses (i.e., 19\%). However, as the analysis shows, the subjects related to informatics have not escaped the traditional educational subject. For example, informatics includes basic subjects such as databases, information retrieval, and information systems, but very few schools cover technological trends such as big data and data science. This phenomenon is similar to the results obtained by Siddiqui [18]. Compared to the UK, LIS education in India includes information on traditional information and communication technologies, but it does not effectively reflect the topics that have been adapted to changes in information technology, such as information law, information architecture, and design for the web. Note that it is not enough to reflect in-demand technologies like big data and data science, despite the discussion of recent trends and needs [27,28]. In fact, only 16 of 214 courses have been established that focus on big data (7), data science and data analysis (4), data visualization (2), and data curation (3). It is necessary to take into account specific schemes for applying new subjects, although we cannot investigate whether these topics are covered in the existing courses. This paper has the following limitations:

- Lack of information about curricula: The title of a subject is a key term reflecting the content of the curriculum but does not include specific details on the contents of the curriculum. The analysis in this paper determined whether the titles of subjects matched but did not deal with the semantic relationship between the contents of the education. Therefore, additional information was collected from the curriculum's educational contents, and analysis is required to link the curriculum with its contents.

- Data collection: This paper collected and analyzed curriculum information published on web pages. The information may be updated according to the department's policy. Therefore, the data collected may not be the same as the current curriculum.

- Lack of data on annual curriculum changes: Generally, the curriculum is revised every six months or once a year. The results discussed in this paper need to be extended annually to identify changes in the curriculum in the long term.

\section{Conclusions}

This study investigated the courses offered by the LIS departments of Korean universities. A total of 1124 courses were collected from 34 universities with an LIS department, and each course was classified according to the academic research field classification system. According to a quantitative and network analysis, library/information management, information organization, and information science can be interpreted as the core subjects of LIS. These subjects have the most courses in all universities. Similarly, each course in these subjects has a high value of degree and betweenness centrality. In addition, subjects on the practical application of the theory of LIS, such as employment, special lectures, and seminars, need to be noted. Individual courses may differ somewhat among universities. However, no significant difference was found between universities.

Informatics, as the most rapidly changing area, ranks third in the total classification and has an important position in LIS. IT offers an opportunity to secure new challenges and competitiveness beyond fragmentary application for the effective management of libraries. For example, big data and data science have characteristics of convergence studies and are effective in linking metadata, information organization, and information retrieval, which are major areas of LIS. The importance of informatics at universities in Korea continues to increase, and universities must be considered in a variety of ways.

Although the research background and goals of each university may be slightly different, the curriculum is constantly changing according to the needs of the environment. A number of studies have been conducted examining academic units and specific fields in the curriculum of LIS. However, because the data used in these studies are not publicly available, data must be collected from scratch 
for similar studies. In addition, since most departments change courses every year, data on the subjects must be continuously gathered and updated to enable long-term research on the course of environmental changes or trends at specific points over time. To this end, all data for collection and analysis need to be made available for further research. Future research will include an in-depth analysis of course content and a longitudinal approach to analyzing changes in courses.

Author Contributions: Conceptualization, Y.M., E.S. and G.P.; methodology, Y.M. and H.K.; software, E.S.; validation, Y.M., E.S. and G.P.; investigation, Y.M., E.S. and G.P.; data curation, Y.M., E.S. and G.P.; writing一original draft preparation, Y.M., E.S. and G.P.; writing—review and editing, H.K.; visualization, E.S.; supervision, H.K.; funding acquisition, H.K. All authors have read and agreed to the published version of the manuscript.

Funding: This research was supported by the Chung-Ang University Research Grants in 2019.

Conflicts of Interest: The authors declare no conflict of interest.

\section{References}

1. Rayward, W.B. Library and Information Science: An Historical Perspective. J. Libr. Hist. 1985, 20, 120.

2. Feltham, C. Counselling studies. Br. J. Guid. Couns. 2001, 29, 111-119. doi:10.1080/03069880020019419. [CrossRef]

3. Carlin, A.P. Disciplinary debates and bases of interdisciplinary studies: The place of research ethics in library and information science. Libr. Inf. Sci. Res. 2003, 25, 3-18. [CrossRef]

4. Sugiuchi, M.; Habu, E.; Ueda, S.; Kurata, K.; Miyata, Y.; Koizumi, M. The trend of library and information science research in Japan: A content analysis of research articles. Libr. Inf. Sci. 2011, 66, 127-151.

5. Prebor, G. Analysis of the interdisciplinary nature of library and information science. J. Librariansh. Inf. Sci. 2010, 42, 256-267. [CrossRef]

6. Jae-Whoan, L. What is Wrong with Korean Library and Information Science? J. Korean Libr. Inf. Sci. Soc. 2018, 49, 1-32. [CrossRef]

7. Younghe, N. A Study on the Development of Standard Model for Curriculum Contents; The National Library of Korea: Seoul, Korea, 2012.

8. Lee, S.C. A Case Study of USC SLIS for Improving Library and Information Science Curriculum in Korea. J. Korean Soc. Libr. Inf. Sci. 2012, 46, 341-363. [CrossRef]

9. Bonnici, L.; Burnett, K. Rhizomes in the iField: What Does it Mean to be an iSchool? Knowl. Organ. 2013, 40, 408-413.

10. Mammo, Y. Rebirth of library and information science education in Ethiopia: Retrospectives and prospectives. Int. Inf. Libr. Rev. 2011, 43, 110-120. [CrossRef]

11. Priti, J. Delivery of library and information science curriculum: A joint endeavour among LIS educators and library practitioners at the University of Botswana. Libr. Rev. 2017, 66, 482-504.

12. Carroll, B.C. Information Professionals 2050: Educational Possibilities and Pathways. Inf. Serv. Use 2012, 32, 93-94. [CrossRef]

13. Cronin, B. The waxing and waning of a field: Reflections on information studies education. Inf. Res. 2012, 17, n3.

14. Katuli-Munyoro, P.; Mutula, S.M. Redefining Library and Information Science education and training in Zimbabwe to close the workforce skills gaps. J. Librariansh. Inf. Sci. 2019, 51, 915-926. [CrossRef]

15. Audunson, R.A.; Shuva, N.Z. Digital Library Education in Europe: A Survey. SAGE Open 2016, 6, 2158244015622538. [CrossRef]

16. Aytac, S.; Ma, L.; Potnis, D.; Rorissa, A.; Chen, H.L.; Hu, X. Diversity and multiculturalism of LIS education. Proc. Assoc. Inf. Sci. Technol. 2016, 53, 1-5. [CrossRef]

17. Wyman, A.; Imamverdiyev, M. Global trends and transformations in library science education. Inf. Learn. Sci. 2018, 119, 215-225. [CrossRef]

18. Siddiqui, S.; Walia, P. A Comparative Analysis of Library and Information Science Post Graduate Education in India and UK. Libr. Philos. Pract. 2013, 1, 941.

19. Hu, S. Technology impacts on curriculum of library and information science (LIS)—A United States (US) perspective. Libr. Inf. Sci. Res. 2013, 23, 1-9.

20. Joseph, J.; Aneesh, C. LIS Education in the Digital Era. Int. J. Soc. Relev. Concern 2018, 6, 1. [CrossRef] 
21. Yi, K.; Turner, R. The Current Landscape of the School Librarianship Curricula in USA. J. Educ. Libr. Inf. Sci. 2014, 55, 303-321.

22. Younghee, N. A Study on the Characteristic Changing of the Library and Information Science Curriculum. J. Korean Libr. Inf. Sci. Soc. 2015, 46, 79-107. [CrossRef]

23. Sarah, Y. A Diagnostic Analysis of LIS Curriculum from the Meta-literacy Perspective. J. Korean Soc. Libr. Inf. Sci. 2018, 52, 191-220.

24. Lee, H.K.; Yang, K.; Kim, S.W. Analysis of Collaborative Research Trends in Library and Information Science in Korea. J. Korean Libr. Inf. Sci. Soc. 2019, 50, 191-214.

25. Lee, K.; Jung, H.; Song, M. Weighted Subject-Method Network Analysis of Library and Information Science Studies. J. Korean Soc. Libr. Inf. Sci. 2015, 49, 457-488.

26. Borrego, A. Library and information education in Europe: An overview. BiD Textos Univ. Bibliotecon. Doc. 2015, 35. [CrossRef]

27. Golub, K.; Hansson, J. (Big) Data in Library and Information Science: A Brief Overview of Some Important Problem Areas. J. UCS 2017, 23, 1098-1108.

28. Zhan, M.; Widen, G. Understanding big data in librarianship. J. Librariansh. Inf. Sci. 2017, 51, 561-576. [CrossRef]

(C) 2019 by the authors. Licensee MDPI, Basel, Switzerland. This article is an open access article distributed under the terms and conditions of the Creative Commons Attribution (CC BY) license (http:/ / creativecommons.org/licenses/by/4.0/). 